\title{
Effects of solid olive-mill waste addition to soil on sorption, degradation and leaching of the herbicide simazine
}

\author{
A. Albarrán ${ }^{1}$, R. Celis ${ }^{2}$, M.C. Hermosín ${ }^{2}$, A. López-Piñeiro ${ }^{1}$, \\ J.J. Ortega-Calvo ${ }^{2} \&$ J. Cornejo ${ }^{2}$ *
}

\begin{abstract}
A laboratory study was conducted to investigate the effects of adding an intermediary byproduct of olive oil extraction (alperujo or solid olive-mill waste, SOMW) on the sorption, degradation and leaching of the herbicide simazine in a sandy loam soil. The effect of SOMW addition on soil porosity was also assessed. The soil was amended in the laboratory with SOMW at two different rates (5\% and 10\% w/w). Simazine sorption isotherms showed a great increase in herbicide sorption after SOMW addition to soil; sorption increased with the amount of SOMW added. Incubation studies showed extended persistence by reduced biodegradation of simazine in the soil amended with SOMW compared with the unamended soil. Although the addition of SOMW to soil increased the total porosity, breakthrough curves of simazine in handpacked soil columns showed that SOMW addition retarded the vertical movement of the herbicide through the soil and reduced the total amount of herbicide leached. It appeared that the longer residence time of simazine in the amended soil columns ( $>20$ days) compared with that in the unamended soil column (<20 days) allowed enhanced degradation and/or irreversible sorption under column leaching conditions. The results revealed important changes in herbicide behaviour upon SOMW addition, confirming the need to assess these changes in order to optimize the combined use of organic wastes and soil-applied pesticides.
\end{abstract}

Keywords: solid olive-mill waste, pesticide, simazine, soil management, organic amendment

\section{INTRODUCTION}

$\mathrm{T}$ he current technology of olive oil manufacture consists of milling followed by centrifuging to generate a liquid phase (olive oil) and a solid organic byproduct (alperujo or solid olive-mill waste, SOMW). In the region of Extremadura (Spain), olive oil production generates approximately $39000 \mathrm{t}$ of olive oil and $155000 \mathrm{t}$ of SOMW each year (MAPA 2001). Usually, the SOMW byproduct is sent for further chemical and thermal treatment in order to obtain a lower-quality olive oil, which also generates a final solid residue (SOMW2) with lower organic matter content than the first residue (SOMW).

Addition to agricultural soils has been proposed as an alternative solution to dispose of SOMW, which could be economically and environmentally more interesting than its chemical and thermal treatment. The low organic matter content of most Mediterranean soils along with their erosion

${ }^{1}$ Departamento de Edafología y Química Agrícola, Universidad de Extremadura, Avda de Elvas s/n. 06071 Badajoz, Spain. ${ }^{2}$ Instituto de Recursos Naturales y Agrobiología de Sevilla, CSIC, Apdo 1052, 41080 Sevilla, Spain.

*Corresponding author. Fax: +34 954624002.

E-mail: cornejo@irnase.csic.es problems, aggravated by intensive irrigation, would make SOMW addition particularly useful to enrich the organic matter content of the soils and improve their structural characteristics. In addition, SOMW is free of heavy metals and pathogenic microorganisms, which reduces concern about their use compared with other organic residues such as sewage sludges.

The rates and frequency of the application of organic residues to agricultural soils are usually calculated in terms of nutrient release or content of toxic chemicals, such as nitrate and heavy metals, but rarely do these calculations take into account the effects of these amendments on other compounds applied to land, such as pesticides. In order to optimize the use of organic wastes as soil amendments in agriculture, this kind of side-effect needs to be assessed. In fact, increased interest has recently been devoted to the consequences of exogenous sources of organic matter on the behaviour of pesticides in soils (Bellin et al. 1990; Barriuso et al. 1995; Baskaran et al. 1996; Businelli 1997; Cox et al. 1997, 2001; Sánchez-Camazano et al. 2000).

In this article, we report the effects of the addition of the first byproduct of the current olive oil industry (solid olivemill waste, SOMW) on sorption, degradation and leaching of the herbicide simazine in a sandy loam soil. Simazine 
sorption by soil has been related to mineral and organic soil components and their associations (Celis et al. 1998a,b). The soil was sampled from an olive-growing area and simazine was selected for study because of its widespread use in olivegrowing areas of Mediterranean regions, which has resulted in ground and surface water contamination above the permitted limit of $0.1 \mu \mathrm{g} \mathrm{L}{ }^{-1}$ (Tauler et al. 2001). Because organic amendments can affect soil structure by different mechanisms, such as aggregation of soil particles or creation of pore space, the effect of SOMW addition on soil porosity was also investigated.

\section{MATERIALS AND METHODS}

\section{Materials}

The soil used in this study was a sandy loam soil, classified as a Chromic Luvisol, from an olive-growing area located in Badajoz (southwestern Spain). It had a cation exchange capacity of $5.36 \mathrm{cmol} \mathrm{kg}^{-1}$. The soil, which had been treated with simazine during the last 8 years at a rate of $2.3 \mathrm{~kg} \mathrm{ha}^{-1}$, was sampled $(0-25 \mathrm{~cm})$, air-dried, and sieved through a $2-\mathrm{mm}$ mesh before use. The soil was amended in the laboratory with 0,5 and $10 \%(\mathrm{w} / \mathrm{w})$ of solid olive-mill waste (SOMW) from an olive-processing factory near Badajoz. The solid waste was air-dried and ground to a fine powder before its addition to the soil. The amended soils were thoroughly mixed to mimic the most likely practice on farms, in which the waste is surface-applied and immediately incorporated into the topsoil. Assuming an average soil bulk density of $1.35 \mathrm{~g} \mathrm{~cm}^{-3}$ and that the amendment is incorporated into the top $10 \mathrm{~cm}$ of soil, the SOMW application rates used, $5 \%$ and $10 \% \mathrm{w} / \mathrm{w}$, correspond to about 60 and $120 \mathrm{tha}^{-1}$, respectively. These SOMW application rates are similar to those that are likely to be used on farms (about $50 \mathrm{tha}^{-1} \mathrm{yr}^{-1}$ ) and are within the application rates used for other solid residues, such as sewage sludges (Sloan et al. 1998). Although $10 \%$ is somewhat higher than the expected concentration for an annual application rate, this loading can be achieved in the field after consecutive annual applications. Some physicochemical characteristics of the organic waste and the unamended and amended soils are given in Table 1.

Simazine (2-chloro-4,6-bis(ethylamino)-1,3,5-triazine) is a non-selective herbicide commonly used in olive-growing areas of Mediterranean regions. It is a colourless solid of melting point $=226^{\circ} \mathrm{C}$, vapour pressure $=810 \times 10^{-9} \mathrm{~Pa}$ $\left(20^{\circ} \mathrm{C}\right)$, and water solubility $=5 \mathrm{mg} \mathrm{L}^{-1}\left(20^{\circ} \mathrm{C}\right)$ (Worthing \& Hance 1991). The herbicide used in this study was high purity simazine (purity $=99 \%$ ) supplied by Riedel-de Haën (Germany). Ring-UL- ${ }^{14} \mathrm{C}$-simazine (specific activity $\geqslant 5 \mathrm{mCi} \mathrm{mmol}^{-1}$, radiochemical purity $\geqslant 95 \%$ ) was purchased from Sigma (Germany).

\section{Sorption-desorption experiment}

Duplicate samples of $10 \mathrm{~g}$ of unamended or amended soil were equilibrated $(24 \mathrm{~h})$ with $10 \mathrm{~mL}$ of simazine solutions with initial concentrations, $C_{\mathrm{ini}}=1,2,5,8,10,15$ and $20 \mu \mathrm{M}$, prepared in $0.01 \mathrm{M} \mathrm{CaCl}_{2}$. After equilibration, the suspensions were centrifuged and the equilibrium concentration $\left(C_{\mathrm{e}}\right)$ was determined in the supernatant by high
Table 1. Physicochemical properties of the soils and the organic amendment.

\begin{tabular}{lccccc}
\hline & $\% \mathrm{OC}$ & $\mathrm{pH}\left(\mathrm{H}_{2} \mathrm{O}\right)$ & $\%$ Sand & $\%$ Silt & $\%$ Clay \\
\hline Unamended soil & 0.56 & 5.3 & 54 & 35 & 11 \\
Amended soil (5\% SOMW) & 2.21 & 5.0 & 54 & 35 & 11 \\
Amended soil (10\% SOMW) & 4.54 & 4.8 & 54 & 35 & 11 \\
SOMW & 50.7 & 5.3 & - & - & - \\
\hline
\end{tabular}

OC, organic carbon; SOMW, solid olive-mill waste.

performance liquid chromatography (HPLC). The following HPLC conditions were used: Nova-Pack C18 column $(150 \mathrm{~mm}$ length $\times 3.9 \mathrm{~mm}$ i.d.), $70: 30$ water/acetonitrile eluent mixture at a flow rate of $1 \mathrm{~mL} \mathrm{~min}^{-1}, 25 \mu \mathrm{L}$ injection volume, and UV detection at $230 \mathrm{~nm}$. Preliminary experiments had shown that equilibrium was reached before 24 hours and that no significant degradation occurred during this period. Differences between $C_{\mathrm{ini}}$ and $C_{\mathrm{e}}$ were assumed to be sorbed. Sorption isotherms were fitted to the logarithmic form of the Freundlich equation:

$\log C_{\mathrm{s}}=\log K_{\mathrm{f}}+N_{\mathrm{f}} \log C_{\mathrm{e}}$

where $C_{\mathrm{s}}\left(\mu \mathrm{mol} \mathrm{kg}{ }^{-1}\right)$ is the amount of herbicide sorbed at the equilibrium concentration, $C_{\mathrm{e}}\left(\mu \mathrm{mol} \mathrm{L}{ }^{-1}\right)$, and $K_{\mathrm{f}}$ and $N_{\mathrm{f}}$ are the empirical Freundlich constants.

Desorption was measured immediately after sorption by successive dilution from the 5,10 and $20 \mu \mathrm{M}$ initial concentration points. After the samples were shaken and centrifuged, $5 \mathrm{~mL}$ of supernatant was removed and analysed and $5 \mathrm{ml}$ of $0.01 \mathrm{M} \mathrm{CaCl}_{2}$ added to the centrifuge tubes. The samples were resuspended, shaken for another 24 hours, centrifuged, and the equilibrium concentration in the supernatant was determined. This desorption procedure was conducted three times.

\section{Incubation experiment}

Extractability. A sample of $500 \mathrm{~g}$ of soil (unamended or amended) was spiked with $5.7 \mathrm{~mL}$ of an ethanol solution of simazine to give a concentration of $2.3 \mathrm{mg} \mathrm{kg}^{-1}$ of dry soil. After evaporation of the solvent, the moisture content was adjusted to $40 \%$ field capacity, and then soil samples were thoroughly mixed by passing them through a $2-\mathrm{mm}$ sieve at least four times. Herbicide-treated soil samples were transferred to glass jars where they were incubated at $20^{\circ} \mathrm{C}$ for 72 days. The moisture content was maintained at a constant level throughout the experiment by adding distilled water as necessary. The soils were sampled periodically and frozen until analysed. Herbicide residues were extracted by shaking $10 \mathrm{~g}$ of duplicate soil samples with $15 \mathrm{~mL}$ of methanol for $24 \mathrm{~h}$ and extracts were analysed by HPLC. Methanol-extractable simazine was assumed to correspond to herbicide present in a potentially available form, and was used to distinguish between available herbicide residues in the soil and degraded or irreversibly bound herbicide (Cox $\&$ Walker 1999).

Mineralization. Portions of unamended or amended soil $(25 \mathrm{~g})$ were placed in $250 \mathrm{~mL}$ glass biometer flasks (Bellco glass) and spiked with $0.285 \mathrm{~mL}$ of an ethanol solution of ring-UL- ${ }^{14} \mathrm{C}$-simazine $(80000 \mathrm{dpm})$ and enough nonlabelled herbicide to give a concentration of $2.3 \mathrm{mg} \mathrm{kg}^{-1}$ of 
dry soil. After evaporation of the solvent, the moisture content was adjusted to $40 \%$ field capacity and maintained at constant level throughout the experiment. The flasks were closed with rubber stoppers and incubated at $20^{\circ} \mathrm{C}$ for a period of 7 weeks. The side arm of the biometer flask contained $1 \mathrm{~mL}$ of $0.5 \mathrm{M} \mathrm{NaOH}$ to trap any ${ }^{14} \mathrm{CO}_{2}$ released during the experiment. The $\mathrm{NaOH}$ solution was sampled periodically and replaced with fresh alkali. The amount of ${ }^{14} \mathrm{CO}_{2}$ in the vials was determined by mixing the $1-\mathrm{mL}$ aliquot of $\mathrm{NaOH}$ solution with $5 \mathrm{~mL}$ of Beckman Ready Safe Scintillation cocktail, followed by radioactivity measurement in a LD 5000 TD Beckman liquid scintillation analyser.

\section{Leaching experiment}

Leaching was studied in $30 \times 5 \mathrm{~cm}$ methacrylate columns made up of six, 5-cm long sections sealed with silicon. The top ring was filled with sea sand and the bottom ring with sea sand plus glass wool, to minimize losses of soil and contamination of leachates with soil particles. The other four rings were hand-packed with $600 \mathrm{~g}$ of unamended or amended soil. The bulk density of the soil columns $\left(1.53 \mathrm{~g} \mathrm{~cm}^{-3}\right)$ was found to be very similar to that of undisturbed field samples $\left(1.49 \mathrm{~g} \mathrm{~cm}^{-3}\right)$. The soil columns were saturated with $0.01 \mathrm{M} \mathrm{CaCl}_{2}$ and allowed to drain for $24 \mathrm{~h}$. The calculated pore volume of the columns after saturation was $175 \pm 2 \mathrm{~mL}$ for the unamended soil, $189 \pm 3 \mathrm{~mL}$ for the soil amended with 5\% SOMW, and $210 \pm 3 \mathrm{~mL}$ for the soil amended with $10 \%$ SOMW. The amount of simazine corresponding to its maximum application rate in soils $\left(2.3 \mathrm{~kg} \mathrm{ha}^{-1}\right)$ was applied to the top of the columns dissolved in $2.25 \mathrm{~mL}$ of methanol, which was allowed to evaporate for $24 \mathrm{~h}$ to minimize its effect on simazine transport. The columns were leached with $0.01 \mathrm{M}$ $\mathrm{CaCl}_{2}$ at a rate of $50 \mathrm{~mL}$ day $^{-1}$ until no herbicide was detected in the leachates. Leachates containing the herbicide were collected daily, filtered and analysed by HPLC. At the end of the leaching experiment, soil samples $(20 \mathrm{~g})$ from the different rings were extracted once with $30 \mathrm{~mL}$ of methanol by shaking mechanically at $20 \pm 2^{\circ} \mathrm{C}$ for $24 \mathrm{~h}$. The suspensions were centrifuged, filtered, and analysed by HPLC in order to determine the residual amount of simazine at the different depths of the soil column. Preliminary experiments showed that this extraction procedure recovered $>95 \%$ of the herbicide freshly applied to the soil. The leaching experiment was conducted in triplicate.

At the end of the leaching experiment, an aliquot of soil $(1 \mathrm{~g})$ was sampled from the bottom ring of the columns, dried at $90^{\circ} \mathrm{C}$ for $24 \mathrm{~h}$, and its pore size distribution (from $4 \times 10^{4}$ to $3.7 \mathrm{~nm}$ ) was determined by mercury intrusion porosimetry using a Carlo Erba 2000 mercury intrusion porosimeter. A value for the surface tension of mercury of $\gamma=0.48 \mathrm{~N} \mathrm{~m}^{-1}$ and a mercury solid contact angle of $\theta$ $=171.3^{\circ}$ were assumed to use the Washburn (1921) equation for the calculation of the pore size distributions.

\section{RESULTS AND DISCUSSION}

Sorption-desorption isotherms

Simazine sorption on soil greatly increased upon SOMW addition (Figure 1, Table 2). Sorption increased with the amount of SOMW added, clearly indicating the role of the organic amendment in simazine sorption. While the simazine sorption isotherm on unamended soil was L-type $\left(N_{\mathrm{f}}<1\right)$ according to the Giles et al. (1960) classification, a higher degree of linearity was observed for the sorption isotherms on amended soil, in particular for the soil amended with $10 \% \operatorname{SOMW}\left(N_{\mathrm{f}} \approx 1\right.$, Table 2$)$. Linear isotherms have previously been reported for the sorption of triazine herbicides, which may reflect the principal role of organic matter in the retention mechanism (Chiou 1989; Celis et al. 1998a; Cox et al. 2001). The fact that variability between $K_{\mathrm{f}}$ values was greatly reduced after normalization to the organic carbon content $\left(K_{\mathrm{f}-\mathrm{oc}}\right.$ values in Table 2$)$ indicates that organic matter played a fundamental role in simazine retention by the soils studied (Hamaker \& Thompson 1972). These $K_{\mathrm{f}-\mathrm{oc}}$ values are similar to those reported for simazine sorption on soil organic matter (Celis et al. 1998b, Cox et al. 2001). It should be noted that conventional batch equilibrations produce sorption coefficients that do not represent slow sorption and non-equilibrium effects, which are likely to operate in field conditions. Therefore, a realistic modelling description of sorption under soil conditions would require a kinetic formulation of the sorption process. Nevertheless, in terms of relative values, a significant increase in simazine sorption after SOMW addition to land can be expected from our data.

Simazine desorption branches from three different concentrations showed in general low or even negative hysteresis for both unamended and amended soils (Figure 2 ), which indicates a high reversibility of the sorptiondesorption process. Cases of negative hysteresis (i.e. the desorption branch lies below the sorption isotherm) have previously been found in sorption-desorption studies with triazine herbicides and were related to highly reversible sorption mechanisms (Barriuso et al. 1994; Celis et al. 1997). Figure 2 shows that reversibility from high concentration points was even greater than that from low concentration points. This is probably the result of sorption site heterogeneity where irreversible, high energy sorption sites are occupied first, that is, at lower herbicide concentration (Celis \& Koskinen 1999). The soil amended with 10\% SOMW displayed ill-defined desorption isotherms, because the very high simazine sorption by this soil resulted in very low solution concentrations, which complicated the desorption analysis (Barriuso et al. 1994).

\section{Effect of SOMW amendment on the persistence of simazine in soil}

For both unamended and amended soils, the amount of simazine extractable with methanol decreased with incubation time (Figure 3a). This behaviour is usually a combination of irreversible sorption and degradation of the chemical during the course of the incubation experiment. Although at short incubation times (i.e. $<20$ days), the amount of simazine extracted from the amended soils was similar or even less than that from the unamended soil, at longer incubation times the amounts of herbicide extracted from the amended soils were significantly greater than those from the untreated soil. Thus, at the end of the incubation 


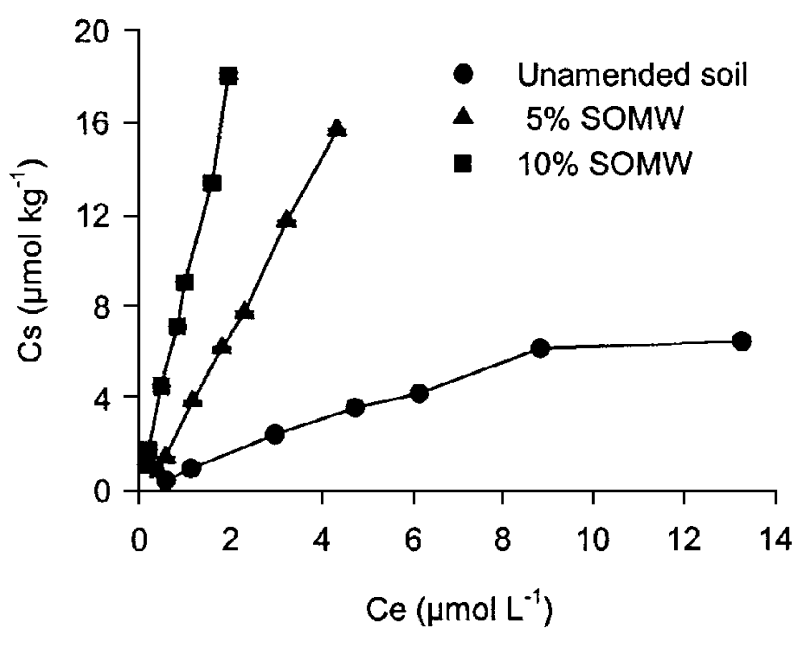

Figure 1. Simazine sorption isotherms on unamended and amended soil.

Table 2. Freundlich coefficients for simazine sorption on unamended and amended soil. ${ }^{\mathrm{a}}$

\begin{tabular}{lcccc}
\hline Soil & $K_{\mathrm{f}}$ & $N_{\mathrm{f}}$ & $R^{2}$ & $K_{\mathrm{f}-\mathrm{oc}}{ }^{\mathrm{b}}$ \\
\hline Unamended & $0.94 \pm 0.10$ & $0.82 \pm 0.06$ & 0.975 & $167 \pm 17$ \\
Amended (5\% SOMW) & $2.99 \pm 0.11$ & $1.16 \pm 0.04$ & 0.995 & $135 \pm 5$ \\
Amended (10\% SOMW) & $8.80 \pm 0.20$ & $0.99 \pm 0.03$ & 0.996 & $193 \pm 4$ \\
\hline
\end{tabular}

${ }^{\mathrm{a}}$ Value \pm standard error; ${ }^{\mathrm{b}}$ organic carbon-normalized $K_{\mathrm{f}}$ value. SOMW, solid olive-mill waste.

experiment ( 72 days), $50 \%$ of the herbicide applied to the soil amended with SOMW remained extractable, whereas a negligible amount of simazine was extractable from the original soil. Considering the amounts extractable with methanol as a measure of the amount of herbicide potentially available for transport and biological processes, these results indicate prolonged availability of simazine in the soil amended with SOMW compared to the unamended soil.

The extractability curve of simazine in the unamended soil showed a sharp decrease after a lag period of about 20 30 days (Figure 3a), which is characteristic of microbial degradation of pesticides utilized as microbial growth substrate (Kearney et al. 1997). Similarly, mineralization results showed that $30 \%$ of the ${ }^{14} \mathrm{C}$-simazine applied to the original soil was mineralized to ${ }^{14} \mathrm{CO}_{2}$ within 50 days (Figure 3b), also indicating that microbial degradation was a major cause of simazine disappearance in the unamended soil. Besides mineralization, irreversible sorption and formation of simazine degradation products different from $\mathrm{CO}_{2}$ may have also contributed to reduce the extractability of simazine during the incubation experiment. In contrast to the unamended soil, very little mineralization of simazine occurred in the SOMW-amended soil (Figure 3b), strongly indicating that the greater extractability of simazine from the amended soils observed in Figure $3 \mathrm{a}$ at longer incubation times was due to reduced microbial degradation. These results are in contrast to other studies where organic amendments promoted pesticide degradation in soil by stimulating microbial activity (Felsot \& Dzantor 1990; Guo et al. 1993). Possible causes for our finding are reduced availability of simazine to microorganisms as a result of
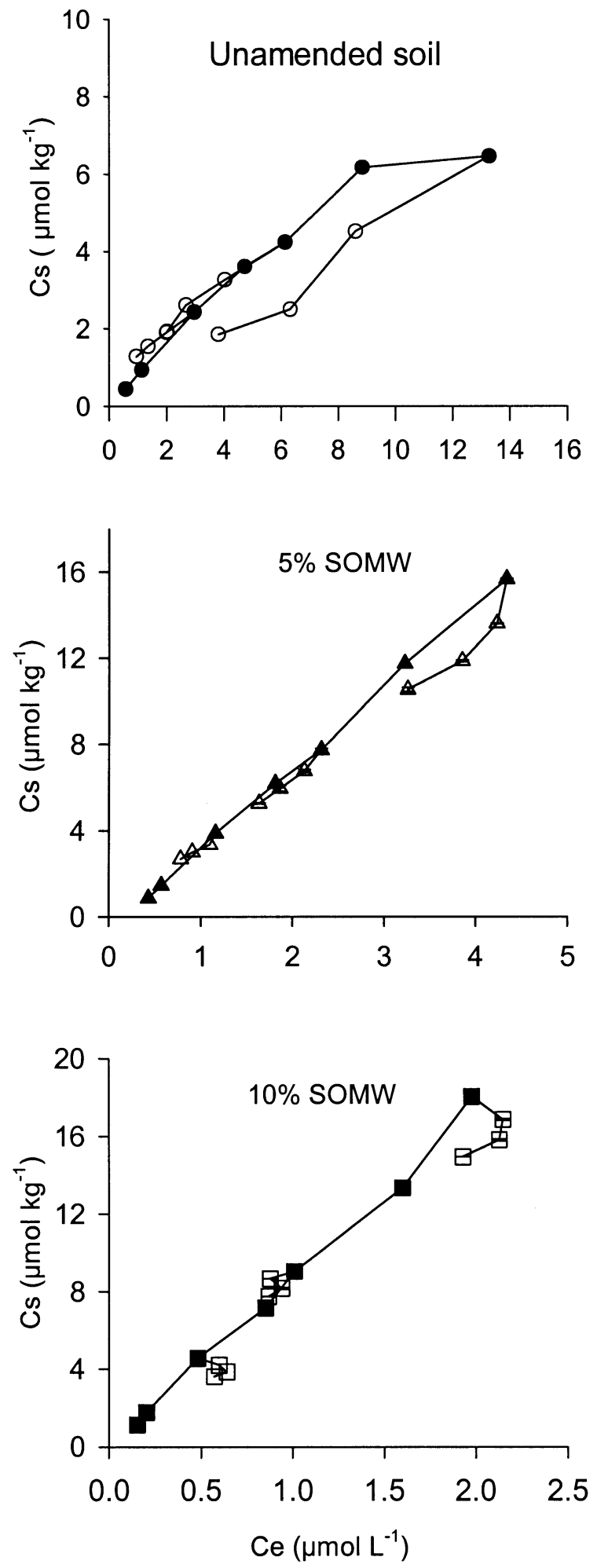

Figure 2. Simazine sorption-desorption isotherms on unamended and amended soil. Solid symbols are sorption points and open symbols are desorption points.

herbicide sorption to the organic amendment, or a toxic effect of the organic amendment on the soil microbial population. Alternatively, soil microorganisms in SOMWamended soil may have preferentially used the organic 

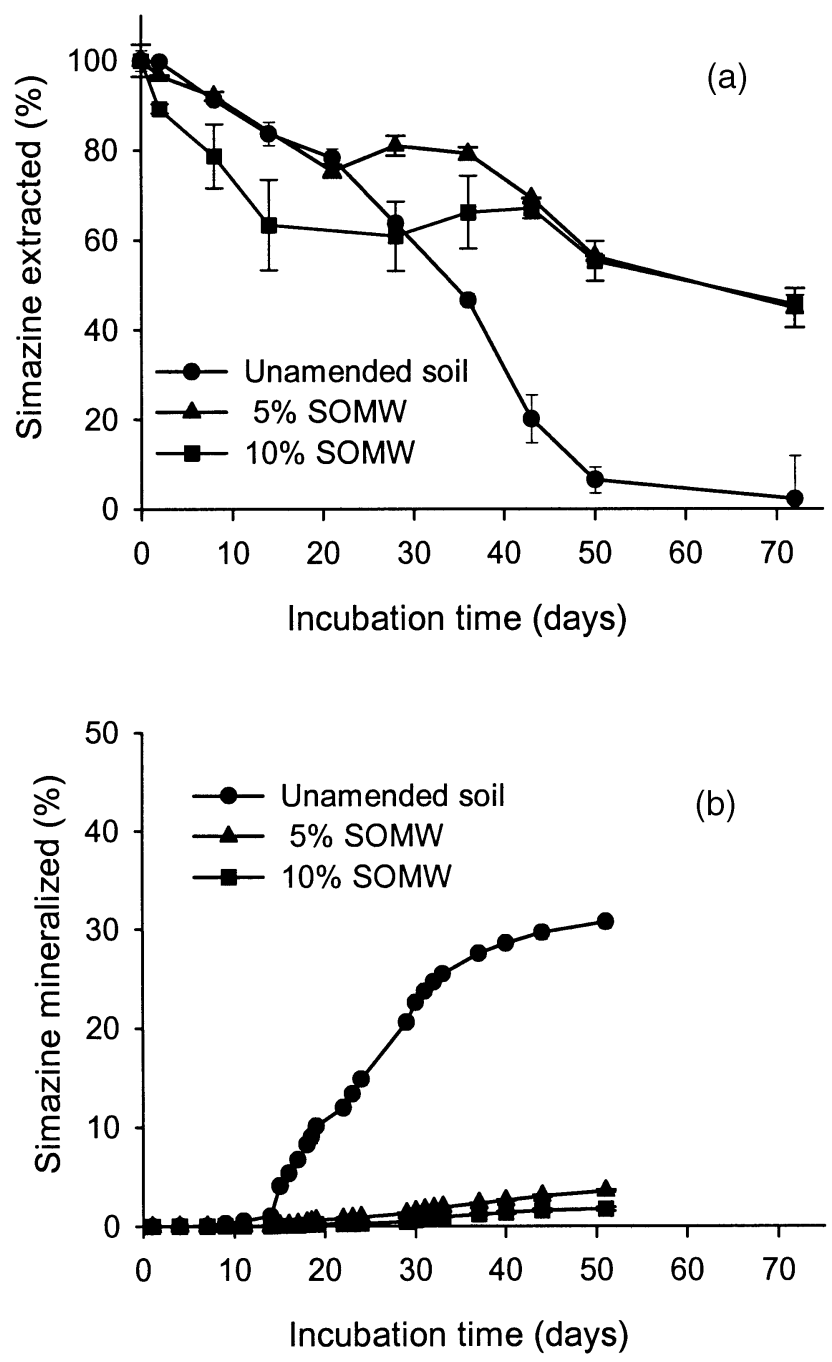

Figure 3. Extractability (a) and mineralization (b) of simazine in unamended and amended soil.

matter of SOMW as a carbon and energy source instead of simazine, but at the same time retaining the ability to slowly degrade the herbicide through co-metabolic reactions that do not cause it to release $\mathrm{CO}_{2}$ (Bollag \& Liu 1990). Whatever the mechanism, our results showed that SOMW significantly extended the persistence of simazine in SOMW-amended soils by reducing the rate of microbial degradation.

\section{Leaching study}

Figure 4 shows relative and cumulative breakthrough curves of simazine in unamended and amended soil columns. A great decrease in simazine concentrations in leachates following SOMW addition to the soil was observed. The maximum concentration of simazine in leachates decreased from $4 \mu \mathrm{M}$ in the unamended soil to $2 \mu \mathrm{M}$ in the soil amended with $5 \%$ SOMW and to $1 \mu \mathrm{M}$ in the soil amended with $10 \%$ SOMW. In addition, retardation of simazine breakthrough as a result of SOMW addition to the soil is evident in Figure $4 \mathrm{a}$, where the position of the maximum concentration peak
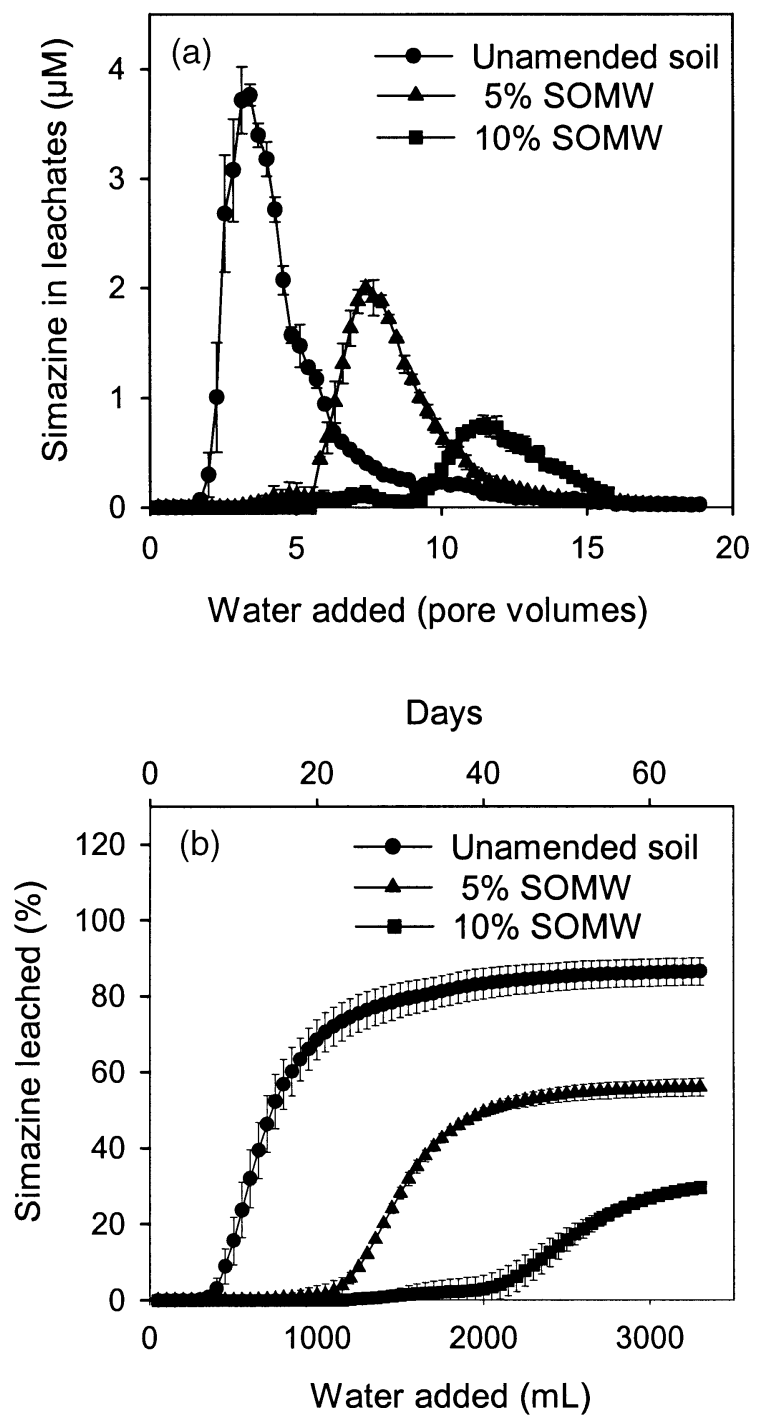

Figure 4. Simazine breakthrough curves (BTCs) in unamended and amended soil: (a) relative BTCs; (b) cumulative BTCs.

shifted from $550 \mathrm{~mL}$ of water added (11 days) in the unamended soil to $1400 \mathrm{~mL}$ ( 28 days) and $2500 \mathrm{~mL}$ ( 50 days) in the amended soils. These results are similar to those reported by Cox et al. (1997), where addition of olive-mill wastewater to soil greatly retarded the vertical movement of the herbicide metamitron in handpacked soil columns. The authors concluded that both an increase in sorption and a reduction of soil porosity contributed to retard the movement of metamitron in the amended soil.

The pore size distributions of our soils, showing an increase in the volume of pores with radii about $10 \mu \mathrm{m}$ after SOMW addition (Figure 5), could not account for the slower breakthrough of simazine in the amended soil (Cox et al. 1997). This suggests that the sorptive properties provided by the organic matter of SOMW, more than a change in soil porosity, was responsible for the slower leaching of simazine observed in the amended soils. This is supported by the good correlation $\left(R^{2}=0.96\right)$ found between simazine retardation in soil columns (position of the 
Table 3. Simazine leached, extracted from the soil column, and not recovered during the leaching experiment. ${ }^{\mathrm{a}}$

\begin{tabular}{lccc}
\hline Soil & $\begin{array}{c}\text { Leached } \\
(\%)\end{array}$ & $\begin{array}{c}\text { Extracted } \\
(\%)\end{array}$ & $\begin{array}{c}\text { Not recovered } \\
(\%)\end{array}$ \\
\hline Unamended soil & $87 \pm 2$ & 0 & 13 \\
Amended soil (5\% SOMW) & $56 \pm 1$ & $10 \pm 5$ & 34 \\
Amended soil (10\% SOMW) & $27 \pm 4$ & $21 \pm 9$ & 52 \\
\hline
\end{tabular}

${ }^{a}$ Value \pm standard error. SOMW, solid olive-mill waste.

maximum concentration peak) and the Freundlich $K_{\mathrm{f}}$ values obtained in batch experiments for the different soils (Table 2) (Beck et al. 1993).

Cumulative breakthrough curves of simazine (Figure $4 \mathrm{~b}$ ) show that total amounts of simazine leached from the soil columns were significantly less for the amended soil $(56 \%$ and $27 \%$ ) than for the original soil (87\%). Although some herbicide was extracted from the amended soil columns at the end of the leaching experiment (Table 3), a significant amount of the simazine applied to the amended soil columns was not recovered, either in leachates or by extraction of the soil after the leaching experiment. In contrast to batch sorption and degradation data, it appears that under column leaching conditions, SOMW addition enhanced degradation and/or irreversible sorption of simazine. This could have been the result of the longer residence time of the herbicide in the amended soil columns ( $>20$ days) compared with that in the unamended soil column ( $<20$ days) (Figure 4$)$, which could have enhanced those processes. In any case, SOMW addition led to slower breakthrough and reduced leaching of simazine, suggesting that the use of this organic amendment may be helpful in decreasing the risk of groundwater contamination associated with leaching losses of simazine from the topsoil.

\section{CONCLUSION}

Addition of the first byproduct of the olive oil extraction technology (solid olive-mill waste, SOMW) to a sandy loam soil at application rates of $5 \%$ and $10 \%(\mathrm{w} / \mathrm{w})$ greatly influenced sorption, degradation and leaching of the herbicide simazine under laboratory conditions. The organic amendment enhanced sorption of simazine, which retarded its vertical movement through soil columns. Incubation studies showed much less mineralization and longer persistence of simazine in the soil amended with SOMW compared with the unamended soil. Since the most likely practice on farms would be incorporation of the waste into the top $20 \mathrm{~cm}$ of soil, our results indicate that SOMW application to agricultural land is likely to increase the residence time of simazine in the topsoil by enhancing sorption and reducing leaching and degradation losses. Although, in terms of absolute values, sorption and degradation in the field may differ from those measured under laboratory conditions, our data strongly indicate that SOMW application could be useful to minimize losses of simazine from the topsoil, preventing loss of biological activity and decreasing the risk of offsite movement from the intended target area. This could allow the farmer to reduce
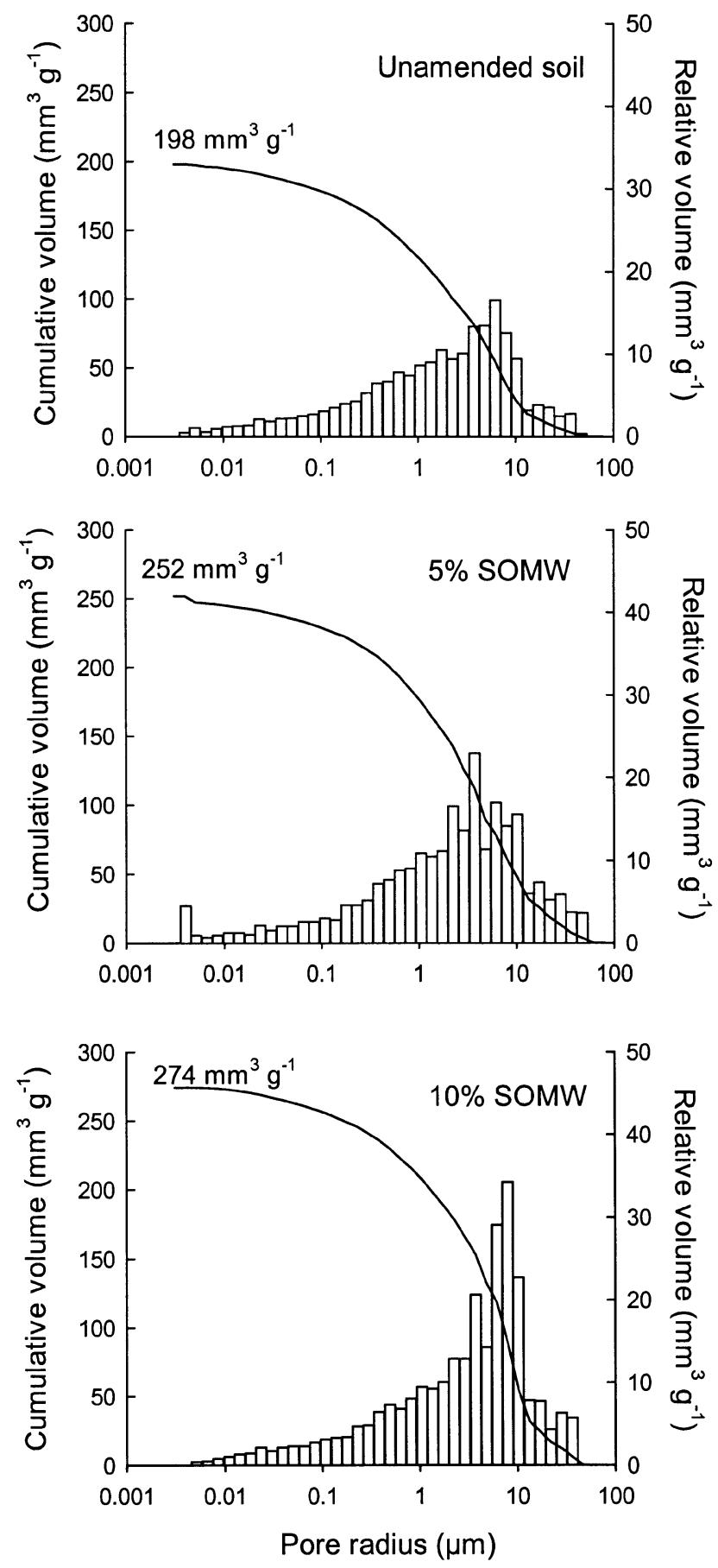

Figure 5. Relative (bars) and cumulative (curves) mercury pore volume of unamended and amended soil.

the rates and frequency of simazine application while maintaining weed control efficacy. In summary, the results of this study illustrate how organic waste addition to soil can influence the fate of other compounds used in agriculture, such as pesticides, revealing the importance of assessing these side-effects in order to optimize the use of soil amendments in agriculture as well as the soil-applied pesticide doses. 


\section{ACKNOWLEDGEMENT}

This work has been partially financed by the projects IFD 97-2222-C03-01 and CAO-01-010, IPR00C012. A. Albarrán thanks the Junta de Extremadura for his FPI fellowship.

\section{REFERENCES}

Barriuso E Laird DA Koskinen WC \& Dowdy RH 1994. Atrazine desorption from smectites. Soil Science Society of America Journal 58, 1632-1638.

Barriuso E Calvet R \& Houot S 1995. Field study of the effect of sewage sludge application on atrazine behaviour in soil. International Journal of Environmental and Analytical Chemistry 59, 107-121.

Baskaran S Bolan NS Rahman A \& Tillman RW 1996. Effect of exogenous carbon on the sorption and movement of atrazine and 2,4-D by soils. Australian Journal of Soil Research 34, 609-622.

Beck AJ Johnston AEJ \& Jones KC 1993. Movement of nonionic organic chemicals in agricultural soils. Critical Reviews in Environmental Science and Technology 23, 219-248.

Bellin CA O'Connor GA \& Jin Y 1990. Sorption and degradation of pentachlorophenol in sludge-amended soils. Journal of Environmental Quality 19, 603-608.

Bollag JM \& Liu SY 1990. Biological transformation processes of pesticides In: Pesticides in the soil environment, ed HH Cheng, SSSA Book Series 2, Soil Science Society of America Madison WI pp 169-211.

Businelli D 1997. Pig slurry amendment and herbicide coapplication effects on s-triazine mobility in soil: an adsorption-desorption study. Journal of Environmental Quality 26, 102-108.

Celis R \& Koskinen WC 1999. Characterization of pesticide desorption from soil by the isotopic exchange technique. Soil Science Society of America Journal 63, 1659-1666.

Celis R Cornejo J Hermosín MC \& Koskinen WC 1997. Sorptiondesorption of atrazine by model soil colloidal components. Soil Science Society of America Journal 61, 436-443

Celis R Barriuso E \& Houot S 1998a. Sorption and desorption of atrazine by sludge-amended soil: dissolved organic matter effects. Journal of Enviromental Quality 27, 1348-1356.

Celis R Cornejo J Hermosín MC \& Koskinen WC 1998b. Sorption of atrazine and simazine by model associations of soil colloids. Soil Science Society of America Journal 62, 165-171.

Chiou CT 1989. Theoretical considerations of the partition uptake of nonionic compounds by soil organic matter. In: Reactions and movement of organic chemicals in soils, eds BL Sawhney \& H Brown, SSSA Special Publication 22, Soil Science Society of America Madison WI pp 1-29.
Cox L \& Walker A 1999. Studies on time-dependent sorption of linuron and isoproturon in soils. Chemosphere 38, 2707-2718.

Cox L Celis R Hermosín MC Becker A \& Cornejo J 1997. Porosity and herbicide leaching in soils amended with olive-mill wastewater. Agriculture, Ecosystems and Environment 65, 151-161.

Cox L Cecchi A Celis R Hermosín MC Koskinen WC \& Cornejo J 2001. Effect of exogenous carbon on movement of simazine and 2,4-D in soils: dissolved organic matter effects. Soil Science Society of America Journal $65,1688-1695$

Felsot AS \& Dzantor EK 1990. Enhancing biodegradation for detoxification of herbicide waste in soil. In: Enhanced biodegradation of pesticides in the environment, eds KD Racke \& JR Coats, American Chemical Society Symposium Series 426, Washington DC pp 192-213.

Giles CH McEwan JH Nakwa SN \& Smith D 1960. Studies in adsorption. Part XI. A system of classification of solution adsorption isotherms, and its use in diagnosis of adsorption mechanisms and in measurement of specific surface areas of solids. Journal of the Chemical Society 3, 39733993.

Guo L Bicki TJ Felsot AS \& Hinesly TD 1993. Sorption and movement of alachlor in soil modified by carbon-rich wastes. Journal of Environmental Quality 22, 186-194.

Hamaker JW \& Thompson JM 1972. Adsorption. In: Organic chemicals in the soil environment, eds CAJ Loring \& JW Hamaker, Marcel Dekker New York pp 49-143.

Kearney PC Shelton DR \& Koskinen WC 1997. Soil chemistry of pesticides. In: Encyclopedia of chemical technology, 4th edn, vol 22, John Wiley \& Sons New York pp 419-451.

MAPA 2001. Anuario de estadística de 2001. Ministerio de Agricultura, Pesca y Alimentación, Madrid.

Sánchez-Camazano M Sánchez-Martín MJ \& Delgado-Pascual R 2000. Adsorption and mobility of linuron in soils as influenced by soil properties, organic amendments, and surfactants. Journal of Agricultural and Food Chemistry 48, 3018-3026.

Sloan JJ Dowdy RH \& Dolan MS 1998. Recovery of biosolids-applied heavy metals sixteen years after application. Journal of Environmental Quality 27, 1312-1317.

Tauler R Azevedo DD Lacorte S, Céspedes R Viana P \& Barceló D 2001. Organic pollutants in surface waters from Portugal using chemometric interpretation. Environmental Technology 22, 1043-1054.

Washburn EW 1921. Note on a method of determining the distribution of pore sizes in a porous material. Proceedings of the Natural Academy of Sciences USA 7, 115-116.

Worthing CR \& Hance RJ 1991. The pesticide manual. British Crop Protection Council, Surrey, UK.

Received October 2002, accepted after revision January 2003. 